\title{
AKTIVITAS ANTAGONISME IN VITRO Trichoderma harzianum DAN Trichoderma pseudokoningii TERHADAP PATOGEN LODOH Pinus merkusii ${ }^{1)}$
}

\author{
In Vitro Antagonistic Activity of T. harzianum and T. pseudokoningii againts \\ Damping off Pathogens of P. merkusii
}

\author{
Achmad $^{1)}$, S. Hadi ${ }^{2)}$, S. Harran ${ }^{3)}$, E. Gumbira Sa'id ${ }^{4)}$, B. Satiawiharja ${ }^{5)}$, dan/and M. Kosim Kardin ${ }^{6}$ \\ ${ }^{1)}$ Departemen Silvikultur Fakultas Kehutanan IPB, Jl. Lingkar Akademik Kampus IPB Darmaga kotak pos 168 \\ Bogor 16680, telp. dan faks. (0251) 8626886, e-mail: deptsilvik@,ipb.ac.id atau achmadrm@yahoo.com \\ ${ }^{2)}$ Guru Besar pada Fakultas Kehutanan IPB (almarhum) \\ ${ }^{3)}$ Staf pengajar pada Fakultas MIPA IPB (purnabakti) \\ ${ }^{4)}$ Guru Besar pada Fakultas Teknologi Pertanian IPB \\ ${ }^{5)}$ Staf pengajar pada Fakultas Teknologi Pertanian IPB \\ ${ }^{6}$ Peneliti Utama pada Balitbio Badan Litbang Pertanian Deptan (purnabakti)
}

Naskah masuk : 12 Januari 2010; Naskah diterima : 6 November 2010.

\begin{abstract}
In vitro study on the biological control of damping-off of Pinus merkusii was done during February 1995 - April 1997 at Forest Protection Laboratory, Faculty of Forestry, Bogor Agricultural University. The pathogens, i.e. Rhizoctonia solani and Fusarium oxysporum, were isolated from seed and sprout stick base cut of damping-off infected P. merkusii seedling by direct planting technique. Fungi antagonists, i.e. Trichoderma harzianum and Trichoderma pseudokoningii, were isolated from seed and rhizosphere soil of damping-off infected pine seedlings. Result of antagonistic test by direct method showed that T. harzianum retarded F. oxysporum growth up to $28.75 \%$ on PDA and $27.33 \%$ on MEA. T. harzianum also retarded R. solani growth up to $11.88 \%$ on PDA and $9.38 \%$ on MEA. T. pseudokoningii retarded $F$. oxysporum growth up to $24.38 \%$ on MEA and $13.96 \%$ on PDA. T. pseudokoningii also retarded $R$. solani growth up to $8.75 \%$ on PDA and $9.37 \%$ on MEA. The two antagonists fungi produced chitinase, and T. harzianum degraded chitin of the medium more intensive than T. pseudokoningii. Antagonistic mechanisms that play role are the mycoparasitism, i.e. coiling and clamping R. solani hyphae by T. harzianum and T. pseudokoningii and penetration of R. solani hyphae by T. harzianum, and antibiosis allegedly by the envolvement of chitinase of the two antagonistic fungi.
\end{abstract}

\section{Keywords: Pinus merkusii, in vitro antagonism, Trichoderma harzianum, Trichoderma pseudokoningii, Rhizoctonia solani, Fusarium oxysporum}

\begin{abstract}
ABSTRAK
Studi pengendalian hayati in vitro terhadap serangan patogen lodoh pada semai Pinus merkusii telah dilakukan di laboratorium Perlindungan Hutan Fakultas Kehutanan Institut Pertanian Bogor dari bulan Februari 1996 hingga April 1997. Perolehan fungi fatogenik penyebab lodoh di lakukan melalui isolasi dari benih dan dari potongan pangkal batang kecambah $P$. merkusii yang menunjukkan gejala terserang lodoh dengan teknik tanam langsung. Fungi antagonis diisolasi dari benih dan tanah yang diambil dari daerah perakaran semai $P$. merkusii yang terserang lodoh. Hasil uji antagonisme dengan metode langsung menunjukkan bahwa Trichoderma harzianum menghambat pertumbuhan Fusarium oxysporum hingga $28.75 \%$ dan $27.33 \%$ berturut-turut pada PDA dan MEA, sedang terhadap $R$. solani penghambatannya sebesar $11.88 \%$ dan $9.38 \%$ berturut-turut pada PDA dan MEA. Penghambatan T. pseudokoningii terhadap pertumbuhan $F$. oxysporum pada MEA mencapai $24.38 \%$, sedang pada PDA sebesar $13.96 \%$. terhadap R. solani. T. pseudokoningii menghambat hingga $8.75 \%$ dan $9.37 \%$ berturut-turut pada PDA dan MEA. Kedua jenis fungi antagonis menghasilkan kitinase, dan T. harzianum lebih intensif mendegradasi kitin pada medium dibanding T. pseudokoningii. Mekanisme antagonistik yang berperan adalah mikoparasitism yaitu pelilitan dan penjepitan hifa $R$. solani berturut-turut oleh $T$. harzianum dan T. pseudokoningii serta
\end{abstract}


penetrasi hifa $R$. solani oleh hifa T. harzianum, dan antibiosis yang diduga melibatkan aktivitas kitinase kedua jenis fungi antagonis.

Kata kunci: Pinus merkusii, antagonisme in vitro, Trichoderma harzianum, Trichoderma pseudokoningii, Rhizoctonia solani, Fusarium oxysporum

\section{PENDAHULUAN}

Pinus merkusii Jungh. et de Vriese merupakan salah satu jenis pohon utama asli Indonesia yang disarankan ditanam pada pembangunan hutan tanaman industri (HTI). Jenis tanaman ini disamping dapat menghasilkan kayu untuk bahan bangunan, bahan korek api, terpentin dan gondorukem, juga di manfaatkan sebagai bahan baku pembuatan pulp untuk menghasilkan kertas.

Pembangunan HTI yang berimplikasi dengan penanaman pohon sejenis pada skala luas menuntut tersedianya bibit berkualitas tinggi dalam jumlah yang cukup. Serangan patogen lodoh yang disebabkan oleh Fusarium oxyporum dan Rhizoctonia solani dapat merupakan satu di antara beberapa penyebab utama berkurangnya jumlah semai yang disediakan. Intensitas serangan lodoh sangat bervariasi dan dapat mencapai 100\% (Suharti et al., 1991).

Perlindungan semai $P$. merkusii terhadap patogen lodoh dapat terjadi melalui faktor semainya sendiri, dalam hal ini berkaitan dengan ketahanan, ataupun melalui manipulasi kondisi lingkungan. Fenomena di lapangan menunjukkan bahwa ketahanan semai $P$. merkusii terhadap penyakit lodoh makin meningkat dengan bertambahnya umur. Perubahan sifat yang terjadi secara alami dengan bertambahnya umur tersebut diduga berkaitan dengan peningkatan ketahanan semai terhadap penyakit lodoh.

Perlindungan semai $P$. merkusii melalui manipulasi faktor lingkungan dapat dilakukan dengan pengendalian patogen secara hayati yang pada akhir-akhir ini mendapat perhatian besar. Lodoh merupakan penyakit pada semai pinus yang disebabkan oleh patogen tular tanah. Oleh karena itu pengendalian hayati dapat efektif mengendalikan penyakit tersebut dan hasilnya dapat berjangka panjang, bahkan permanen, serta tidak mengakibatkan polusi atau gangguan bagi kesehatan manusia dan hewan (Bruehl, 1987).

Pengendalian hayati dilakukan antara lain melalui introduksi antagonis yang dapat menghambat patogen dan kolonisasinya pada rizosfer. Penghambatan tersebut terjadi melalui mekanisme antagonistik yang antara lain melibatkan peran enzim dan metabolit lain yang di hasilkan antagonis. Fungi antagonis Trichoderma sp. dan Gliocladium sp. dilaporkan mampu menghambat patogen lodoh (Baker dan Cook, 1974). Di Indonesia, upaya pengendalian hayati penyakit lodoh pada $P$. merkusii yang disebabkan oleh Fusarium sp., Pythium sp., dan Rhizoctonia sp. menggunakan fungi antagonis Trichoderma sp. diteliti oleh Sudjud (1983). Hasilnya menunjukkan bahwa fungi antagonis mampu menghambat ketiga patogen lodoh tersebut antibiosis.

Mekanisme pengendalian hayati dapat terjadi dalam bentuk antibiosis, kompetisi, dan mikoparasitisme (Baker dan Cook, 1974). Antibiosis adalah antagonisme yang diperantarai oleh metabolit spesifik atau non-spesifik, atau oleh agensia lisis, enzim, senyawa folatil, atau zat beracun (toksin) lainnya yang dihasilkan oleh mikroba (Fravel, 1988). Kompetisi biasanya terjadi terhadap nutrisi dan ruang tumbuh atau faktor-faktor pertumbuhan penting tertentu lainnya. Interaski mikoparasitik secara umum dibedakan ke dalam dua tipe, yaitu tipe biotrofik dan tipe nekrotrofik. Kebanyakan interaksi mikoparasitik yang mempengaruhi struktur bertahan patogen tular tanah adalah tipe nekrotrofik (Lockwood, 1988).

Tujuan penelitian ini adalah untuk mempelajari efektivitas penghambatan in vitro fungi antagonis $T$. harzianum dan $T$. pseudokoningii terhadap pertumbuhan patogen lodoh $R$. solani, dan $F$. oxysporum serta mekanisme penghambatan yang terjadi.

\section{BAHAN DAN METODE}

Percobaan dilaksanakan di Laboratorium Perlindungan Hutan Fahutan IPB dari Februari 1996 hingga April 1997. Penelitian diawali dengan penyediaan inokulum fungi melalui isolasi dan seleksi isolat, kemudian dilanjutkan dengan perlakuan terhadap isolat terpilih sesuai tujuan tiap tahap kegiatan penelitian.

Perolehan fungi patogenik penyebab lodoh dilakukan melalui isolasi dari benih dan dari potongan pangkal batang kecambah $P$. merkusii yang menunjukkan gejala terserang lodoh dengan teknik tanam langsung. Isolasi dari benih 
dilakukan dengan menanam benih secara langsung pada media agar air dan PDA (Potato Dexrose Agar). Benih yang ditanam adalah benih yang permukaannya tidak disterilkan maupun yang disterilkan terlebih dahulu dengan merendamnya dalam larutan $\mathrm{NaOCl} 1 \%$ selama 2-5 menit dan dibilas dengan air steril satu kali.

Isolasi dari pangkal batang dilakukan dengan prosedur berikut : potongan pangkal batang yang terserang patogen lodoh dicuci dengan air steril dalam labu Erlenmeyer, kemudian permukaannya disterilkan dengan merendam dalam larutan $\mathrm{NaOCl}$ 1\% selama dua menit dan dibilas dengan air steril tiga kali, serta selanjutnya dikeringkan dengan cara meletakkannya dalam cawan petri bersih yang telah dialasi kertas saring steril. Potongan pangkal batang tersebut kemudian ditanam pada media agar air dan PDA dan diinkubasi pada suhu kamar. Setelah patogen tumbuh, kemudian isolat dimurnikan. Dua isolat dari isolat-isolat patogen lodoh yang diperoleh yang paling kuat virulensinya, yaitu yang menimbulkan persentase semai pinus mati terbesar, digunakan pada percobaan selanjutnya.

Fungi antagonis diisolasi dari benih dan tanah yang diambil di daerah perakaran semai $P$. merkusii yang terserang lodoh. Isolasi dari benih dilakukan bersama-sama dengan isolasi fungi patogen lodoh. Isolasi fungi dari tanah dilakukan dengan cara mengambil contoh tanah sebanyak $10 \mathrm{~g}$ kering udara yang ditempatkan dalam gelas piala, kemudian ke dalamnya ditambahkan air destilata hingga mencapai volume $100 \mathrm{ml}$ (pengenceran $1: 10$ ). Suspensi dikocok, kemudian dituang ke dalam labu Erlenmeyer $250 \mathrm{ml}$ dan dikocok kembali. Secara aseptik diambil $10 \mathrm{ml}$ dari suspensi tersebut dan diencerkan dengan $90 \mathrm{ml}$ air destilata steril (pengenceran $1: 100$ ). Selanjutnya, dari suspensi yang telah diencerkan tersebut dibuat seri pengenceran 1 : 1000, dan 1 : 10000 dengan menambah air destilata steril. Dari tiap tingkat pengenceran, dituangkan $1 \mathrm{ml}$ suspensi ke media agar air dan PDA yang telah ditambah antibiotik kemisetin 50 ppm dalam cawan petri secara aseptik. Cawan petri beserta isinya kemudian ditempatkan pada suhu kamar selam 24 jam, miselia yang tumbuh dipotong kemudian dipindahkan ke medium PDA yang baru, dan selanjutnya biakan fungi dimurnikan.

Berdasarkan pemurnian dan uji antagonistik, dua isolat Trichoderma sp. dipilih untuk digunakan pada tahap percobaan selanjutnya. Isolat Trichoderma sp. yang pertama memiliki karakteristik sebagai berikut : hifa berukuran diameter 4-6 $\mu \mathrm{m}$, fialospora membulat dengan permukaan licin berukuran 2.5-3 x 3-4 $\mu \mathrm{m}$, fialid berukuran 9-12 $\times$ 3-4 $\mu \mathrm{m}$, dan klamidospora berukuran diameter 9-13 $\mu \mathrm{m}$. Fialospora bulat dengan permukaan licin merupakan karakteristik Trichoderma harzianum (Rifai, 1969). Sedang karakteristik isolat Trichoderma sp. yang kedua adalah : hifa berukuran diameter 3- $5 \mu \mathrm{m}$, fialospora lonjong, berukuran 3.5-4 x 2-2.5 $\mu \mathrm{m}$, fialid berukuran 6-9 x 3-3.5 $\mu \mathrm{m}$, dan klamidispora berukuran diameter 6-9 $\mu \mathrm{m}$. Biakannya menunjukkan pewarnaan kekuningan hingga kuning pada PDA yang merupakan karakteristik Trichoderma pseudokoningii (Rifai, 1969).

Pengujian antagonisme dengan metode langsung pada media padat di lakukan terhadap kombinasi pasangan isolat fungi patogen dan antagonis. Media yang di gunakan adalah PDA dan MEA (Malt Extract Agar), dengan mengikuti prosedur yang diterangkan Marx (1969).

Potongan koloni antagonis dan patogen di tanam pada media PDA dan MEA dalam cawan petri pada saat yang sama, dengan jarak antara koloni $5 \mathrm{~cm}$. Potongan koloni tersebut diambil dari biakan murni antagonis atau patogen berumur 5 hari dengan menggunakan bor gabus diameter $6 \mathrm{~mm}$. Cawan petri beserta isinya kemudian ditempatkan pada suhu kamar. Pengujian dilakukan dalam tiga ulangan.

Peubah yang diamati adalah presentase penghambatan fungi patogen oleh fungi antagonis dan lebar zona hambatan. Presentase penghambatan (p) dihitung dengan persamaan (1) (Fokkema 1973 dalam Skidmore, 1976). Pada persamaan ini, $\mathrm{p}$ menunjukkan presentase penghambatan, rl adalah jari-jari koloni fungi patogen yang tumbuh berlawanan arah terhadap fungi antagonis, sedang $\mathrm{r} 2$ adalah jari-jari koloni fungi patogen yang tumbuh ke arah fungi antagonis. Lebar zona hambatan adalah lebar zona antara kedua ujung koloni fungi, diukur pada hari ke lima setelah fungi patogen ditanam.

$$
\mathrm{P}=\frac{\mathrm{r}_{1}-\mathrm{r}_{2}}{\mathrm{r}_{1}} \times 100 \%
$$

Pengamatan mikroskopik miselia pada daerah pertemuan antara dua koloni yaitu fungi antagonis dan fungi patogen dilakukan untuk mengetahui mekanisme penekanan terhadap patogen yang mungkin terjadi. Uji kualitatif produksi kitinase fungi antagonis dilakukan dengan menumbuhkan kedua jenis fungi tersebut 
pada media kitin agar (Atlas, 1993). Adanya produksi kitinase ditandai dengan adanya perubahan media yang awalnya putih keruh menjadi transparan. Hal ini menunjukkan adanya konsumsi kitin oleh fungi antagonis karena fungi tersebut menghasilkan kitinase.

\section{HASIL DAN PEMBAHASAN}

Hasil uji antagonisme dengan metode langsung menunjukkan bahwa Trichoderma harzianum menghambat pertumbuhan Fusarium oxysporum hingga $28.75 \%$ dan $27.33 \%$ berturut-turut pada PDA dan MEA, sedang terhadap Rhizoctonia solani penghambatannya sebesar $11.88 \%$ dan $9.38 \%$ berturut-turut pada PDA dan MEA ( Tabel 1).
Antagonisme antara T. harzianum dengan kedua jenis fungi patogen menimbulkan terbentuknya zona hambat, baik pada PDA maupun MEA. Lebar zona hambatan terhadap koloni $F$. oxysporum mencapai $5.8 \mathrm{~mm}$ dan 6.4 $\mathrm{mm}$ berturut-turut pada PDA dan MEA. Zona tersebut lebih lebar dibanding yang terbentuk pada antagonisme antara fungi antagonis yang sama dengan $R$. solani, yaitu hanya selebar 2.4 $\mathrm{mm}$ dan $1.6 \mathrm{~mm}$ berturut-turut pada PDA dan MEA(Tabel 1).

Penghambatan $T$. pseudokoningii terhadap pertumbuhan $F$. oxysporum pada MEA mencapai $24.38 \%$, sedang pada PDA sebesar $13.96 \%$. Terhadap $R$. solani, $T$. pseudokoningii menghambat hingga $8.75 \%$ dan $9.37 \%$ berturut-turut pada PDA dan MEA (Tabel 2)

Table (Table) 1. Penghambatan pertumbuhan in vitro F. oxysporum dan R. solani oleh T. harzianum pada PDA dan MEA ( In vitro growth inhibition of F. oxysporum and R. solani by T. harzianum on PDA and MEA)

\begin{tabular}{|l|c|c|c|}
\hline $\begin{array}{c}\text { Fungi patogen } \\
\text { (Pahogenic fungi) }\end{array}$ & $\begin{array}{c}\text { Media } \\
(\text { Medium })\end{array}$ & $\begin{array}{c}\text { Penghambatan } \\
\text { (Inhibition) } \\
(\%)^{1)}\end{array}$ & $\begin{array}{c}\text { Lebar zona hambatan } \\
\text { (Width of inhibition zone) } \\
(\mathrm{mm})^{1)}\end{array}$ \\
\hline F. oxysporum & PDA & $28.75 \pm 4.79$ & $5.8 \pm 0.64$ \\
R. solani & MEA & $27.33 \pm 8.03$ & $6.4 \pm 0.95$ \\
& PDA & $11.88 \pm 2.39$ & $2.4 \pm 0.48$ \\
& MEA & $9.38 \pm 3.14$ & $1.6 \pm 0.48$ \\
\hline
\end{tabular}

${ }^{1)}$ nilai pada tiap kolom peubah : rataan \pm simpangan baku (values in each column: average \pm standard deviation)

Table (Table) 2. Penghambatan pertumbuhan in vitro F. oxysporum dan R. solani oleh T. pseudokoningii pada PDA dan MEA (In vitro growth inhibition of $\mathrm{F}$. oxysporum and R. solani by T. pseudokoningii on PDA and $M E A)$

\begin{tabular}{|l|c|c|c|}
\hline $\begin{array}{c}\text { Fungi patogen } \\
\text { (Pahogenic fungi) }\end{array}$ & $\begin{array}{c}\text { Media } \\
(\text { Medium })\end{array}$ & $\begin{array}{c}\text { Penghambatan } \\
(\text { Inhibition }) \\
(\%)^{1)}\end{array}$ & $\begin{array}{c}\text { Lebar zona hambatan } \\
\text { (Width of inhibition zone }) \\
(\mathrm{mm})^{1)}\end{array}$ \\
\hline F. oxysporum & PDA & $13.96 \pm 5.76^{1)}$ & $0.0^{2)} \pm 0.00^{1)}$ \\
R. solani & MEA & $24.38 \pm 3.14$ & $5.5 \pm 0.95$ \\
& PDA & $8.75 \pm 3.23$ & $0.0^{2)} \pm 0.48$ \\
& MEA & $9.37 \pm 2.39$ & $1.5 \pm 0.82$ \\
\hline
\end{tabular}

1) nilai pada tiap kolom peubah : rataan \pm simpangan baku (values in each column: average \pm standard deviation)

2) pertumbuhan fungi patogen terhambat tetapi tidak terbentuk zona hambatan antar kedua koloni (the growth of the pathogen was inhibited but inhibition zone between colonies was not formed)

Pada antagonisme antara kedua jenis fungi patogen dengan T. pseudokoningii, terbentuknya zona hambatan tergantung pada media yang digunakan. Antagonisme T. pseudokoningii dengan $F$. oxysporum pada PDA tidak terbentuk zona hambatan, akan tetapi pada MEA terbentuk selebar $5.5 \mathrm{~mm}$ (Tabel 2 ). Fenomena yang sama juga ditemukan pada antagonisme T. pseudokoningii dengan
$R$. solani, yaitu pada PDA tidak terbentuk zona hambatan akan tetapi pada MEA terbentuk selebar $1.5 \mathrm{~mm}$ (Tabel 2). Kemampuan antagonistik kedua jenis fungi antagonis juga ditunjang oleh pertumbuhannya yang lebih pesat dibanding fungi patogen pada PDA maupun MEA.

Hasil pengamatan mikroskopik miselia pada daerah pertemuan antara kedua koloni 
menunjukan bahwa hifa $T$. harzianum tumbuh melilit hifa $R$. solani. Disamping itu terjadi penetrasi oleh hifa T. harzianum dan penjepitan oleh hifa T. pseudokoningii terhadap hifa $R$. solani (Gambar 1).
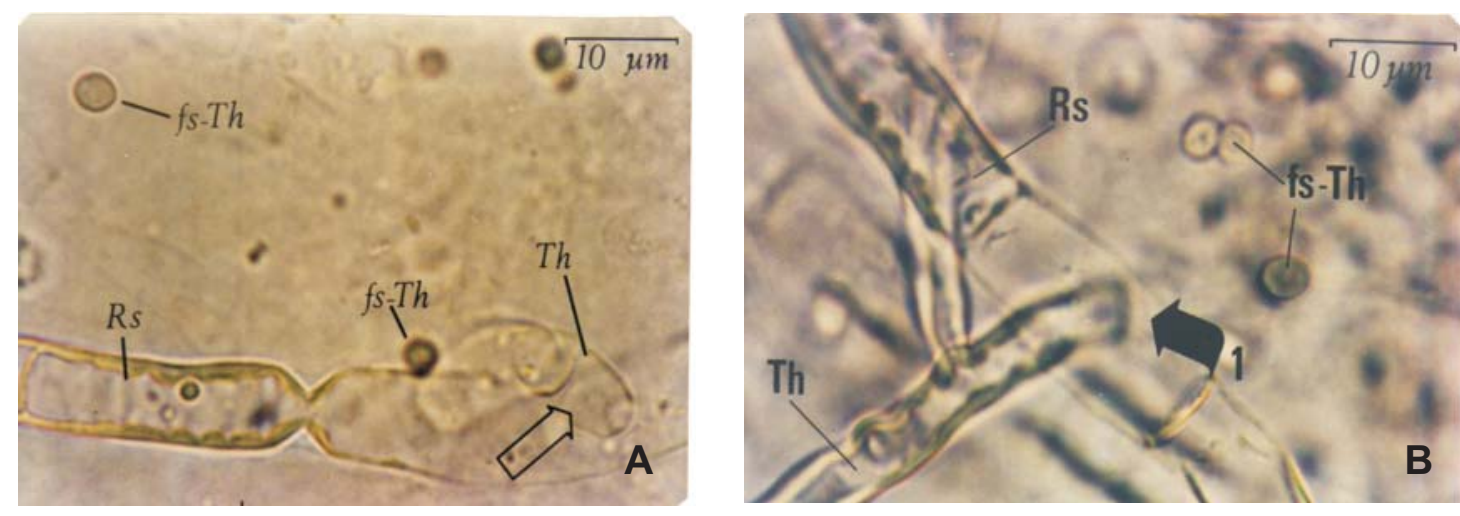

Gambar(Figure) 1. Mikrograf daerah pertemuan koloni antagonis patogen. A: pelilitan hifa R. solani oleh hifa T. harzianum. Th: T. harzianum, Rs: R. solani, fs-Th: fialospora T. harzianum, tanda anak panah: pelilitan hifa. B: Penetrasi hifa $R$. solani oleh hifa $T$. harzianum mengakibatkan isi sel hifa $R$. solani kosong. Th: T. harzianum, Rs: $R$. solani, fs-Th: fialospora T. harzianum, tanda anak panah 1: penetrasi hifa (Micrographs of antagonist - pathogens colony meeting area. A: hyphae coiling of $\mathrm{R}$. solani by $\mathrm{T}$. harzianum. Th: T. harzianum, $R s$ : R. solani, $f_{s}-T h$ : phialospora of T. harzianum, arrows mark: hyphae coiling. B: Penetration of hyphae of $\mathrm{R}$. solani by $\mathrm{T}$. harzianum resulted in the contents of cells of R. solani empty. Th: T. harzianum, Rs: R. solani, $f_{s-}$ Th: phialospora of T. harzianum, arrows mark 1: hyphae penetration)

Hasil pengujian kualitatif menunjukan bahwa T. harzianum dan $T$. pseudokoningii menghasilkan kitinase. Hal tersebut ditunjukkan oleh berubahnya media agar kitin yang pada awalnya putih keruh menjadi transparan, karena terjadi degradasi kitin pada media oleh enzim yang dihasilkan kedua jenis fungi (Gambar 2). T. harzianum lebih intensif mendregdasi kitin pada media dibanding $T$. pseudokoningii, dan hal tersebut menunjukkan aktivitas kitinasenya yang lebih tinggi. Hal ini juga menunjukkan bahwa pertumbuhan $T$. harzianum pada agar kitin lebih cepat dibanding pertumbuhan T. pseudokoningii.

Wells (1988) mengemukakan bahwa Trichoderma merupakan antagonis yang potensial. Hasil penelitian mendukung pendapat tersebut. T. harzianum maupun T. pseudokoningii mampu menghambat pertumbuhan koloni kedua jenis fungi patogen berdasarkan hasil percobaan in vitro pada PDA maupun MEA. Kemampuan tersebut menunjukkan bahwa kedua jenis fungi antagonis diharapkan dapat dimanfaatkan sebagai agensia dalam pengendalian hayati penyakit lodoh.

Terdapat tiga mekanisme dalam antagonisme antar jazad renik, yaitu antibiosis, kompetisi, dan mikoparasitisme (Baker and Cook, 1974). Ketiga mekanisme tersebut teramati pada antagonisme yang melibatkan kedua jenis Trichoderma yang diuji dalam penelitian ini.

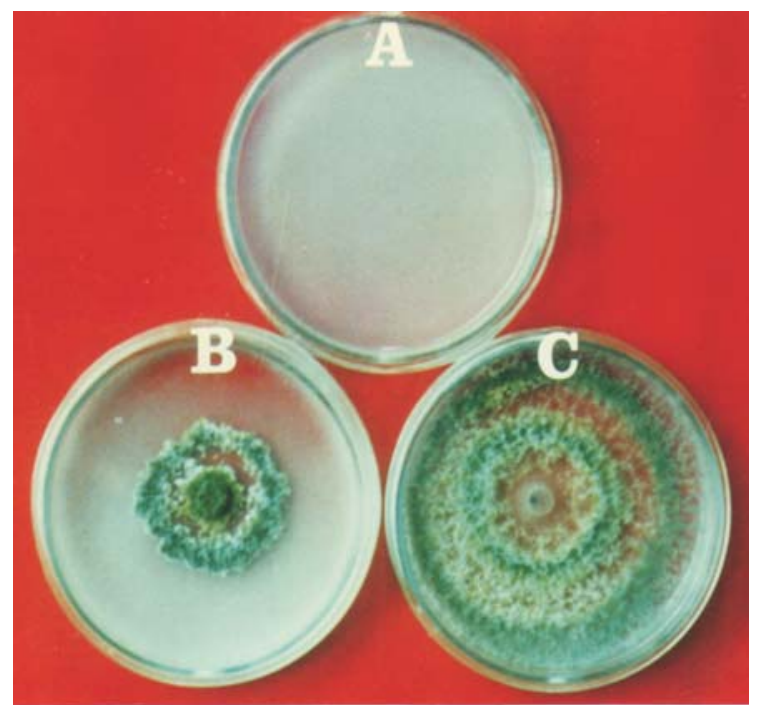

Gambar (Figure) 2. Degradasi kitin pada media agar kitin oleh fungi antagonis. A: kontrol media agar kitin, B: biakan $T$. 
pseudokoningii pada 6 hari setelah tanam (hst), C: biakan T. harzianum pada 6 hst, degradasi kitin pada media mengakibatkan media menjadi transparan sehingga warna merah latar belakang obyek terlihat (Degradation of chitin on chitin agar medium by fungal antagonists. A: chitin agar as control, $B$ : cultured $\mathrm{T}$. pseudokoningii at 6 days after planting (dap) and $C$ : cultured $\mathrm{T}$. harzianum at 6 dap on chitin agar, the degradation of chitin in the medium resulted in a transparent of the medium so that the red color of the background objects become visible)

Wells (1988) mengemukakan bahwa Trichoderma merupakan antagonis yang potensial. Hasil penelitian mendukung pendapat tersebut. T. harzianum maupun T. pseudokoningii mampu menghambat pertumbuhan koloni kedua jenis fungi patogen berdasarkan hasil percobaan in vitro pada PDA maupun MEA. Kemampuan tersebut menunjukkan bahwa kedua jenis fungi antagonis diharapkan dapat dimanfaatkan sebagai agensia dalam pengendalian hayati penyakit lodoh.

Terdapat tiga mekanisme dalam antagonisme antar jazad renik, yaitu antibiosis, kompetisi, dan mikoparasitisme (Baker and Cook, 1974). Ketiga mekanisme tersebut teramati pada antagonisme yang melibatkan kedua jenis Trichoderma yang diuji dalam penelitian ini.

Terbentuknya zona hambatan pada media padat merupakan indikasi bekerjanya mekanisme antibiosis. Pada antagonisme pada media padat yang melibatkan $T$. harzianum, zona hambatan terbentuk baik pada PDA maupun MEA, akan tetapi zona hambatan pada antagonisme yang melibatkan T. pseudokoningii terbentuk hanya pada MEA, sedang pada PDA tidak. Hal tersebut disamping menunjukkan bahwa macam metabolit yang dihasilkan tiap jenis antagonis berbeda, juga menunjukkan bahwa pengaruh metabolit yang dihasilkan T. pseudokoningii pada PDA tersentralisir.

Tersentralisirnya pengaruh metabolit penghambat pertumbuhan patogen pada PDA dilaporkan Achmad (1991). Dikemukakannya bahwa antagonisme in vitro fungi mikoriza Rhizopogon sp. dengan Fusarium sp. maupun Rhizoctonia sp. membentuk zona hambatan pada agar MMN, akan tetapi pada PDA zona tersebut tidak terbentuk. Fenomena yang sama juga dilaporkan oleh Darusman (1996) yang mempelajari potensi antagonistik fungi mikoriza Pisolithus tinctorius dan Scledorma columnare terhadap Fusarium sp. dan Rhizoctonia sp.

Menurut Wells (1988), mekanisme antibiosis dapat melibatkan metabolit beracun (toksin) atau enzim ekstraseluler yang dihasilkan oleh fungi antagonis. Dikemukakan bahwa Trichoderma sp. menghasilkan toksin trikhordermin yang merupakan suatu senyawa sesquiterpen, dermadin yaitu asam berbasa tunggal yang aktif terhadap fungi dengan kisaran yang luas dan meliputi bakteri gram positif dan gram negatif, serta dua senyawa peptida yang bersifat antifungal sekaligus anti bakterial.

Hasil uji kualitatif menunjukkan bahwa $T$. harzianum maupun T. pseudokoningii menghasilkan kitinase. T. harzianum lebih efektif mendregradasi kitin pada media karena media menjadi lebih transparan dibanding media $T$. pseudokoningii. Hal tersebut juga menunjukkan bahwa aktivitas kitinase T. harzianum lebih tinggi dibanding aktifitas kitinase T. pseudokoningii.

Uji produksi kitinase tersebut dilakukan secara kualitatif, sehingga hasilnya tidak dapat menunjukkan macam kitinase yang dihasilkan kedua jenis fungi antagonis, mengingat kitinase merupakan enzim kompleks. Harman et al. (1993) mengidentifikasi enam macam enzim kitinase yang berbeda pada $T$. harzianum. Dikemukakan bahwa kompleksitas dan diversitas sistem enzim tersebut secara komplementer, sehingga tercapai efisiensi maksimal melawan spektrum luas fungi patogen yang mengandung kitin. Hal tersebut sejalan dengan pernyataan Lorito et al. (1993) bahwa enzim kitinolitik T. harzianum secara biologi lebih aktif dibanding enzim yang sama dari sumber lainnya, dan lebih efektif melawan fungi pada kisaran yang lebih luas. Peran kitinase pada antagonisme $T$. harzianum dengan $R$. solani dilaporkan oleh Benhamou dan Chet (1993). Dikemukakan bahwa degradasi kitin fungi patogen terjadi secara bertahap, dan hal tersebut menunjukkan dihasilkannya kitinase secara terus-menerus oleh fungi antagonis.

Disorganisasi struktur dinding sel $R$. solani tampaknya merupakan kejadian awal yang mengakibatkan ketidakseimbangan osmotik internal, yang kemudian memicu kerusakan intraseluler seperti kebocoran membran plasma dan agregasi sitoplasma. Sivan and Chet (1989) mempelajari degradasi dinding sel fungi oleh enzim kitinolitik dari T. harzianum. Dilaporkan bahwa bila dinding sel hifa $F$. oxysporum 
digunakan sebagai sumber karbon pada media biakan T. harzianum, maka fungi antagonis tersebut akan mengeluarkan kitinase dan 1,3-Bglukanase ke dalam media.

Tertekannya pertumbuhan fungi patogen menunjukkan mekanisme kompetisi dalam antagonisme, dalam hal ini fungi antagonis lebih kompetitif dalam memanfaatkan ruang tumbuh dan nutrisi. Lebih kompetitifnya fungi antagonis ditunjang oleh pertumbuhannya yang lebih cepat dibanding fungi patogen pada media yang sama. Keberadaan Trichoderma yang melimpah pada tanah-tanah pertanian di seluruh dunia merupakan bukti terbaik bahwa fungi tersebut merupakan kompetitor yang sangat baik untuk tumbuh dan nutrisi ( Wells, 1988).

Mekanisme mikoparasitisme ditunjukkan oleh hasil pengamatan mikroskopik pada daerah pertemuan miselia $T$. harzianum dan $R$. solani yang antara lain memperlihatkan pelilitan dan penetrasi hifa $R$. solani oleh hifa T. harzianum. Benhamou dan Chet (1993) mengemukakan bahwa pada proses mikoparasitisme $T$. harzianum terhadap $R$. solani, pelilitan hifa $T$. harzianum di sekeliling hifa $R$. solani merupakan fenomena yang mengawali rusaknya hifa patogen.

Elad et al. (1983) mempelajari mikoparasitisme T. harzianum dan T. hamatum terhadap $R$. solani dan Sclerotium rolfsii. Dikemukakan bahwa hifa $T$. harzianum memasuki $R$. solani melalui lubang yang dibuatnya pada hifa inang. Lisis parsial terjadi pada bagian hifa inang yang dililit oleh hifa antagonis. Dikemukakan pula bahwa dalam antagonisme tersebut terdapat indikasi $T$. harzianum mensekresikan B-1,3-glukanase. Fenomena molekuler yang dikemukakan adalah terjadinya pengendapan bahan-bahan fibril ektraseluler antara hifa yang saling beinteraksi, terakumulasinya organel-organel parasit pada sel-sel yang tengah memarasit, dan terbentuknya matriks selubung yang membungkus hifa yang tengah mempenetrasi.

Dari kedua jenis fungi antagonis yang diuji, T. harzianum memiliki potensi antagonistik lebih kuat dibanding T. pseudokoningii. Hal tersebut karena $T$. harzianum menghambat pertumbuhan fungi patogen dengan persentase penghambatan lebih tinggi, mengakibatkan terbentuknya zona hambatan lebih besar, dan menghasilkan kitinase yang lebih efektif mendegradsi kitin dibanding T. pseudokoningii untuk sifat-sifat yang sama.

\section{KESIMPULAN}

1. Fungi antagonis $T$. harzianum dan $T$. pseudokoningii secara in vitro mampu menghambat pertumbuhan kedua jenis fungi patogen lodoh $R$. solani dan $F$. oxysporum. $T$. harzianum lebih kuat menghambat pertumbuhan kedua jenis patogen dibanding T. pseudokoningii.

2. Mekanisme antagonistik yang berperan adalah mikoparasitisme yang ditunjukkan oleh pelilitan hifa $R$. solani oleh $T$. harzianum dan penjepitan hifa $R$. solani oleh $T$. pseudokoningii, serta penetrasi hifa $R$. solani oleh hifa $T$. harzianum, dan antibiosis yang diduga melibatkan aktivitas kitinase kedua jenis fungi antagonis.

3. Kedua jenis fungi antagonis menghasilkan kitinase, dan T. harzianum lebih intensif mendegradasi kitin pada medium dibanding $T$. pseudokoningii.

\section{DAFTAR PUSTAKA}

Achmad. 1991. Kemampuan Rhizopogon sp. untuk Perlindungan Hayati terhadap Penyebab Penyakit Lodoh pada Pinus merkusii. Tesis Magister Sains. Program Pascasarjana IPB, Bogor. $68 \mathrm{hlm}$.

Atlas, R.M. 1993. Handbook of Microbiological Media. CRC Press, Boca Raton, Ann Arbor, London, Tokyo. 1079 p.

Baker, K.F. and R.J. Cook. 1974. Biological Control of Plant Pathogens. W.H. Freeman and Co., San Fransisco. 433 p.

Benhamau, N. and I. Chet. 1993. Hyphal interactions betwen Trichoderma harzianum and Rhizoctonia solani: parasitic process. Phytopathology 83:1062-1071.

Bruehl, G.W. 1987. Soil Borne Plant Pathogens. MacMillan Publ. Co., New York. 368 p.

Darusman, L.K. 1996. Telaah Biokimiawi Proses Asosiasi Shorea selanica dan Scleroderma columnare : Suatu Pendekatan Biosintesis. Disertasi Doktor. Program Pasca Sarjana IPB, Bogor. 173 hlm.

Elad, Y., I. Chet, P. Boyle, and Y. Henis. 1983. Parasitism of Trichoderma spp. on Rhizoctonia solani and Sclerotium rolfsii : 
scanning electron microscopy and flourescence microscopy. Phytopathology $73: 85-88$

Flentje, N.T. 1965. Pathogenesis by Soil Fungi, p. 255-268. In K.N. Baker and W.C. Snyder (Eds.) Ecology of Soil Borne Plant Pathogens. Prelude to Biological Control. University California Press, Berkeley, Los Angeles.

Fravel, D.R. 1988. Role of antibiosis in the biocontrol of diseases. Ann. Rev. Phytopathol. 26:75-81.

Harman, G.E., C.K. Hayes, M. Lorito, R.M. Broadway, A. Di Pietro, C. Petrebauer and A. Tronsmo. 1993. Chitinolytic enzymes of Trichoderma harzianum : purification of chitobiosidase and endochitinase. Phytopathology 83: 313-318.

Lockwood, J.L. 1988. Evolution of concepts associated with soilborne plant pathogens. Ann. Rev. Phytopathol. 26:93-121.

Lorito, M., G.E. Harman, C.K. Hayes, R.M. Broadway, A. Tronsmo, S.L. Woo and A. Di Pietro. 1993. Chitinolytic enzymes produced by Trichoderma harzianum : antifungal activity of purified endochitinase and chitobiosidase. Phytopathology $83: 303-307$.

Manan, S. 1976. Silvikultur. Proyek Pengembangan Peningkatan Perguruan Tinggi IPB, Bogor. $188 \mathrm{hlm}$.

Marx, D.H. 1969. The influence of ectotrophic mycorrhizal fungi on the resistance of pine root to pathogenic infections I. Antagonism of mycorrhizal fungi to root pathogenic fungi and soil bacteria. Phytopathology 59: 153-163.

Marx, D.H. 1973. Mycorrhizae and feeder root diseases, p. 350-381. In_G.C. Marks and T.T. Kozlowski (Eds.) Ectomycorrhizae: their Ecology and Physiology. Academic Press, New York and London.
Rifai, M.A. 1969. A revision of the genus Trichoderma. Mycological Paper no. 16. Commonwealth Mycological Institute, Kew Surrey, England.

Siven, A. and I. Chet. 1989. Degradation of fungal cell by lytic enzymes of Trichoderma harzianum. J. General Microbiol. $135: 675-682$.

Skidmore, A.M. 1976. Interactions in relation to biological control of plant pathogens, $p$. 507-528. In C.H. Dickinson and T.F Preece (Eds.) Microbiology of Aerial Plant Surfaces.. Academic Press, London.

Steel, R.G.D. and J.H. Torrie. 1980. Principles and Procedures of Statistics. A Biomentrical Approach. McGraw-Hill Inc., Tokyo. 633 p.

Suharti, M., T. Hardi, dan R.S.B. Rianto. 1991. Mengenal beberapa hama, penyakit penting pada hutan tanaman industri. Makalah di sampaikan pada Seminar Nasional Peningkatan Produktivitas HTI Melalui Upaya Pengendalian Hama dan Penyakit secara Terpadu. Fahutan IPB Dephut - RI, Bogor, 31 Juli 1991.

Sudjud, D.A. 1983. Tinjauan antagonisme antara Trichoderma sp. dengan Pythium sp., Rhizoctonia sp., dan Fusarium sp. dalam rangka usaha pengendalian/penekanan secara biologis terhadap kerugian akibat dumping-off. Lembaga Penelitian Hutan. Bogor.

Tang, J., J.S. Zhou, K.X. Wang, and W.L. Kiu. 1988. Effects of ectomycorrizal fungi on dumping-off of pines. Forest Pest and Disease (4) : 20-21.

Wells, H.D. 1988. Trichoderma as a biocontrol agent, p. 71-82. In K.G. Mukerji and K.L. Kang ( $E d s$.) Biocontrol of Plant Diseases, vol. I. CRC Press Inc., Boca Raton Florida. 